\title{
Detection of IgG Antibodies against Chlamydophila abortus in Sheep with Reproductive Disorders
}

\author{
M. TRÁVNIČEK ${ }^{1}$, D. KOVÁČOVÁ ${ }^{2}$, M.R. BHIDE ${ }^{1}$, P. ZUBRICKÝ ${ }^{2}$, L. ČISLÁKOVÁ ${ }^{3}$
}

${ }^{1}$ University of Veterinary Medicine, Košice, Slovakia, ${ }^{2}$ State Veterinary Institute, Prešov, Slovakia, ${ }^{3}$ Medical Faculty, University of P.J. Šafárik, Košice, Slovakia

Received May 28, 2002

Accepted March 25, 2003

\section{Abstract}

Trávniček M., D. Kováčová, M.R. Bhide, P. Zubrický, L. Čisláková: Detection of IgG Antibodies against Chlamydophila abortus in Sheep with Reproductive Disorders. Acta Vet. Brno 2003, 72: 95-99.

Chlamydophila (Chl.) abortus is the most important causative agent of the enzootic abortion and other chlamydial infections of sheep. Complement fixation (CF) test is a very useful serological method as screening test, but the diagnosis can be complicated by non-specific, false positive reactions with some Gram-negative bacteria as well as with Chl. pecorum. Diagnosis can be improved by simultaneous use of indirect (i)ELISA. Moderate agreement (Kappa-0.568) between $\mathrm{CF}$ test and iELISA was observed in this study. We observed $36.0 \%(75 / 208)$ positive samples from clinically healthy sheep and $63.2 \%$ (91/144) in the sheep with reproductive disorders by detecting anti-Chl. abortus IgG antibodies using iELISA. When the same sera samples were investigated by CF test, only $13.9 \%$ seropositivity was observed in clinically health sheep whereas in the group with reproductive disorders, positivity observed was $45.8 \%$. Sensitivity and specificity of iELISA used in this study was found to be higher than CF test.

Chlamydophila abortus, IgG antibodies, sheep, iELISA, CF test

Chlamydophila abortus, an etiological agent of enzootic abortion in sheep and goats, may also impair the overall reproductive performance ( $\mathrm{Papp}$ and Shew en 1996). The organism has a zoonotic potential (Buxton 1986; Hyde and Bernis chke 1997), and therefore must be dealt with great care with adequate microbiological precautions and laboratory containment. After revision of the family Chlamydiacae, Everett et al. (1999a) proposed to include this family into two genus, namely Chlamydia (Ch.) and Chlamydophila (Chl.). Genus nov. Chlamydophila abortus (previously Chlamydia psittaci, biotype 1) will substitute Ch. psittaci, the etiological agent for abortion of sheep, goats and cattle.

Complement fixation (CF) test can be used at a herd basis to detect the infective cause of abortion (Trávníček et al. 2001). IgG antibodies against Chl. abortus can be detected with $\mathrm{CF}$ test during active placental infection in the last months of gestation period and following the bacteraemia which often accompanies abortion. A significant level of IgG antibodies against Chl. abortus is possible to detect up to 8 weeks after abortion or parturition. A rise in antibody titre provides a basis for retrospective diagnosis. Antigenic cross-reactivity between Chl. abortus and Chl. pecorum, as well as with some Gram-negative bacteria like Acinetobacter can give rise to low false positive CF test results (Manual of Standards, 2000). False positivity can be avoided by using a more sensitive and specific method like ELISA. In our study we have not checked the cross reactivity of the CF test. Considering the cross reactivity of $\mathrm{CF}$, it is possible to obtain more seropositivity by $\mathrm{CF}$ than ELISA, but the chances of getting more positivity are the least as cross reactive agents are not always present.

Indirect ELISA for detection of chlamydial antibodies in sheep was developed mostly for research purposes (Jones et al. 1997; Kaltenboeck et al. 1997; Salti-Montesanto et

Address for correspondence:

MVDr. M. Trávniček

University of Veterinary Medicine

Kom1 81 Košice, Slovakia
Phone: +421556338180

Fax: +421 556323666

http://www.vfu.cz/acta-vet/actavet.htm 
al. 1997; Gut-Zangger et al. 1999; Kennedy et al. 2001; Longbottom et al. 2001 and Buendia et al. 2001). Nowadays, iELISA kits are available commercially for detection of antibodies against Chlamydophila abortus in animals (Pospíšil et al. 1996; Věžník and Pospíšil 1997 and Buendia et al. 2001). iELISA test is more sensitive and specific as compared to $\mathrm{CF}$ test for detection of antibodies against chlamydias.

Our study aimed at monitoring of IgG antibodies against Chl. abortus in clinically healthy sheep as well as in sheep with reproductive disorders using iELISA and CF test and to compare both these tests.

\section{Materials and Methods}

A total of 208 serum samples were collected from clinically healthy sheep in 9 different farms with no evidence of chlamydial infection (i.e. abortion, stillbirths, pneumonia, conjunctivitis etc.), and 144 serum samples from seven farms of sheep with reproductive disorders. The animals with reproductive disorders were kept separately from the farms where healthy animals are bred. The reproductive disorders were abortion, stillbirths and infertility. The sera were examined by CF test as well as by iELISA. For CF test sera with titre 1:32 and higher were considered as positive (Manual of Standards, 2000). In CF test, we used species-specific antigen of Chlamydophila abortus (Chlamydia psittaci, biotype 1) provided by Bioveta Ivanovice na Hané, Czech Republic.

We used commercially available iELISA kit by Cypress Diagnostics, Leuven, Belgium for detection of antibodies to $C h l$. abortus in ovine serum. The Chl. abortus specific antigen was coated in 96 -well microtitre plate. Specific antibodies to Chl. abortus in diluted serum samples binds with coated antigen and remains attached even after washing with buffer. Anti-sheep antibodies conjugated with HRPO were added to bind with attached anti Chl. abortus antibodies. Substrate (OPD) was added after washing unbound conjugate for chromogenic reaction.

Statistical analysis

CF test and iELISA were evaluated for their sensitivities and specificities and were compared by measuring agreement between tests (Kappa) according to Martin et al. (1988).

\section{Results}

In the group of clinically healthy sheep $(n=208)$, a of total $13.9 \%$ seroprevalence was detected by using CF test. Seroprevalence in these clinically healthy sheep from different

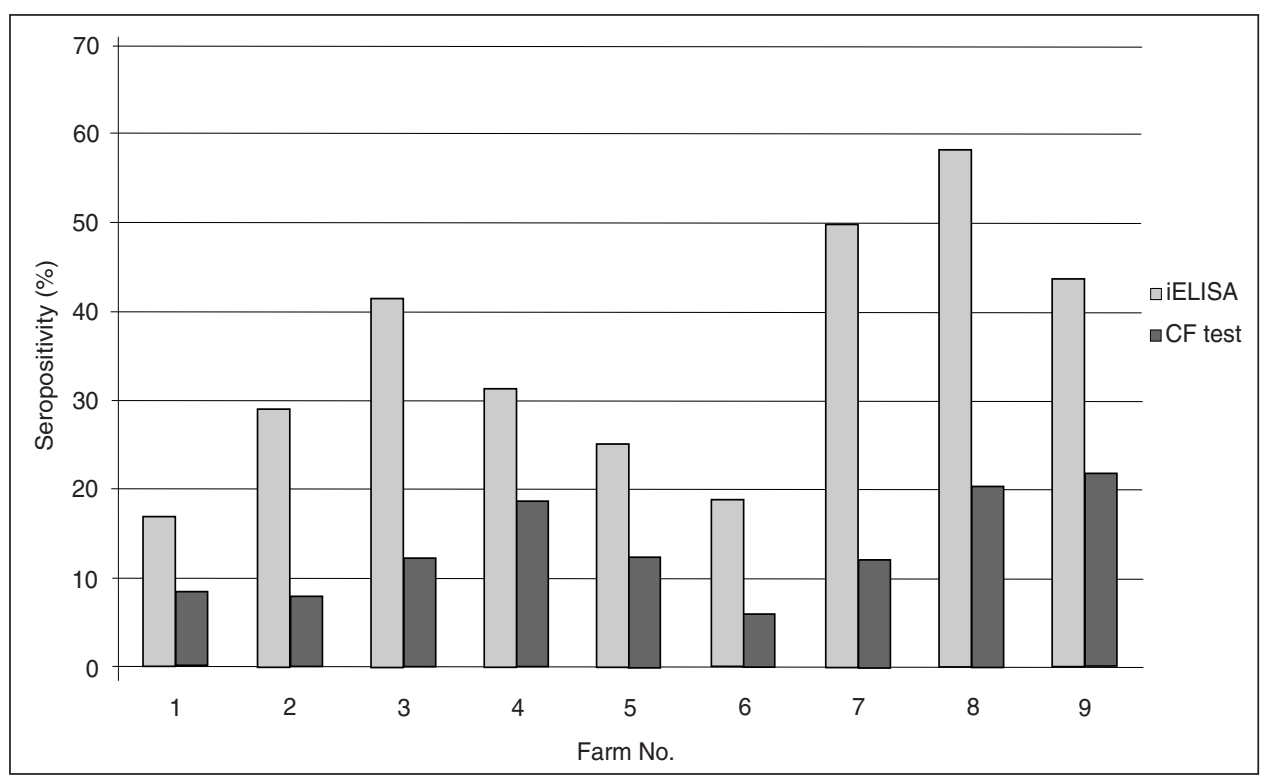

Fig. 1. Detection of IgG antibodies in clinically healthy sheep using iELISA and CF test 


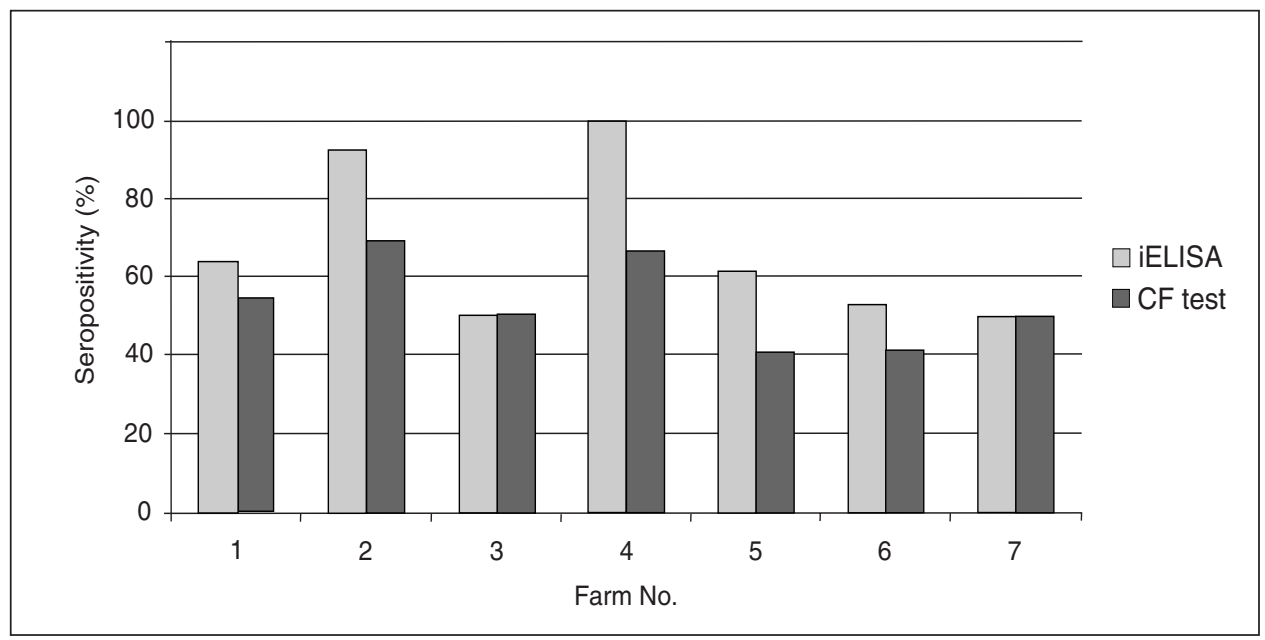

Fig. 2. Detection of IgG antibodies in sheep with reproductive disorders using iELISA and CF test

farms ranged between $6.2-21.9 \%$. When the same group of sheep was screened by iELISA, a total 36.0\% (16.6-58.3\%) seroprevalence was detected (Fig. 1).

In the second group, that is sheep with reproductive disorders $(\mathrm{n}=144)$, seroprevalence was $45.8 \%$ (40.9-69.2) by using CF test, whereas, the same was $63.2 \%(50.0-100.0 \%)$ by using iELISA (Fig. 2).

\section{Discussion}

Kennedy et al. (2001) developed two serological tests viz. indirect immunofluorescence test and ELISA for the detection of fetal antibody to Chl. abortus for diagnosis of ovine abortion. An indirect ELISA (R OMP 91B iELISA) based on recombinant protein fragment of the polymorphic outer membrane protein, POMP91B of Chlamydophila abortus was developed and used by Long bottom et al. (2001). Indirect ELISA proved more sensitive $(84.2 \%)$ and specific (98.5\%) than CF test in experimentally as well as naturally infected sheep. Furthermore, iELISA was found better at differentiating Chlamydophila abortus from Chlamydophila pecorum in infected animals (Longbottom et al. 2001). Our results obtained in sheep with reproductive disorders using iELISA showed $63.2 \%$ positivity, which is significantly higher then positivity obtained with CF test $(45.8 \%)$. The sensitivity and specificity obtained for iELISA as compared to CF test was higher in this study, while both these tests were moderately in agreement (Kappa - 0.568).

A new commercially available ELISA (ELISAr-Chlamydia) for detecting antibodies against Chlamydophila abortus has been evaluated in sheep (Buendia et al. 2001). The ELISA is based on a recombinant antigen, which expresses part of a protein from the 80$90 \mathrm{kDa}$, which is specific to Chlamydophila abortus. A total of 105 sera from six flocks with confirmed ovine chlamydial abortion (OEA), as well as 258 sera from 18 flocks, with out OAE were tested by ELISA with recombinant antigen. The ELISAr-Chlamydia was compared with the CF test and with ELISA using purified Chlamydophila abortus elementary bodies (ELISA-EB). The results showed that the sensitivity of ELISArChlamydia was $90.9 \%$ with a specificity of $85.9 \%$. As compare to above parameters the sensitivity of CF test was $71.0 \%$ with a specificity of $83.6 \%$, whereas, the sensitivity and specificity of ELISA-EB were $95.2 \%$ and $54.2 \%$ respectively. The study demonstrated most 
Table 1

Number of animals tested and farm wise positivity obtained for IgG antibodies in clinically healthy sheep as well as in sheep with reproductive disorders using iELISA and CF test

\begin{tabular}{|c|c|c|c|}
\hline Farm No. & No. of animals & \multicolumn{2}{|c|}{ No. of positive animals } \\
\hline clinically healthy sheep & tested & iELISA & 2 \\
2 & 24 & 7 & 2 \\
3 & 24 & 10 & 3 \\
4 & 24 & 5 & 3 \\
5 & 16 & 6 & 3 \\
6 & 24 & 3 & 1 \\
7 & 16 & 12 & 3 \\
8 & 24 & 14 & 5 \\
9 & 24 & 14 & 26 \\
\hline Total & 32 & 75 & \\
\hline 1 & 208 & 7 & 6 \\
2 & sheep with reproductive disorders & 9 \\
3 & 11 & 12 & 1 \\
4 & 13 & 1 & 2 \\
5 & 2 & 3 & 36 \\
6 & 3 & 54 & 7 \\
7 & 88 & 9 & 5 \\
\hline Total & 17 & 5 & 66 \\
\hline & 10 & 91 & \\
\hline & & & \\
\hline
\end{tabular}

balanced results between sensitivity and specificity for ELISAr-Chlamydia (B uendia et al. 2001). The sensitivity of CF test in our study in the group of sheep with reproductive disorders was $45.8 \%$ that is lower than iELISA but, comparing with the results obtained by Buendia et al. (2001), sensitivity of iELISA used by us was lower. According to Everret et al. (1999) and Everret and Andersen (1999), introducing Polymerase Chain Reaction (PCR) into practice can make possible an exact distinction of invasive and pathogenic species of chlamydiae.

Salti-Montes anto et al. (1997) compared three serological methods viz. competitive (c) ELISA, A-ELISA (containing solubilized outer membrane complexes) and CF test, using 125 field ovine sera. They detected $45.9 \%$ sensitivity for cELISA, $48.8 \%$ for A-ELISA and only $19.2 \%$ for CF test. The prevalences obtained by CF and iELISA in group of clinically healthy sheep and in sheep with reproductive disorders are significantly different $(13.9 \%-45.8 \%$ by $\mathrm{CF}$ and $36.0 \%-63.2 \%$ by iELISA).

Indirect ELISA found to be more sensitive and specific than CF test. It is concluded that an indirect ELISA is suitable as a routine test for chlamydial diagnosis and seroepidemiological studies in sheep.

\section{Detekcia IgG protilátok proti Chlamydophila abortus u oviec s poruchami reprodukcie}

Chlamydophila (Chl.) abortus je najdôležitejším pôvodcom enzootického abortu a iných chlamýdiových infekcií oviec. Komplement fixačný test (KFT) je velmi užitočným sérologickým testom používaným tiež ako screeningový test, výsledky ním dosiahnuté však môžu byt komplikované nešpecifickými, falošne pozitívnymi reakciami s antigénmi niektorých Gram negatívnych baktérií a tiež s Chl. pecorum. Sérodiagnostika môže byt 
upresnená simultánnym použitím nepriamej ELISA metódy. Zistili sme rozdielnoste (Kappa - 0.568) medzi KFT a nepriamou ELISA metódou. Pri použití nepriamej ELISA sme zistili u klinicky zdravých oviec pozitívne hladiny IgG protilátok u 36.0\% zvierat (75/208) a u oviec s poruchami reprodukcie séropozitivita bola $63.2 \%(91 / 144)$. Pri použití KFT u klinicky zdravých oviec séropozitivita dosiahla $13.9 \%$ a v skupine oviec s reprodukčnými poruchami bola $45.8 \%$. Citlivost a špecificita nepriamej ELISA metódy použitej v tejto štúdii bola vyššia ako u KFT testu.

\section{References}

BUXTON, D 1986: Potential danger to pregnant women of Chlamydia psittaci from sheep. Vet. Rec. 3: 510-511 BUENDIA, AJ, CUELLO, F, DEL RIO, L, GALLEGO, MC, CARO, MR, SALINAS, J (2001): Field evaluation of a new commercially available ELISA based on a recombinant antigen for diagnosing Chlamydophila abortus (Chlamydia psittaci serotype 1). Vet Microbiol 78: 229-239

EVERETT, KDE, BUSH, RM, ANDERSEN, AA 1999a: Emended description of the order Chlamydiales, proposal of Parachlamydiacae fam. nov. and Simkaniacae fam. nov., each containing one monotopic genus, revised taxonomy of the family Chlamydiacae, including a new genus and five new species, and standards for the identification of organisms. Int J Syst Bacteriol 49:415-440

EVERETT, KDE, ANDERSEN, AA 1999: Identification of nine species of the Chlamydiaceae using PCR-RFLP. Int J Syst Bacteriol 49: 803-813

EVERETT, KDE, HORNUNG, LJ, ANDERSEN, AA 1999b: Rapid detection of the Chlamydiaceae and other families in the order CHLAMYDIALES: three PCR tests. J Clin Microbiol 37: 575-580

GUT-ZANGGER, P, VRETOU, E, PSARROU, E, POSPISCHIL, A, THOMA, R 1999: Chlamydial abortion in sheep: possibilities of serological diagnosis using a competitive ELISA and insight into the epidemiological situation in Switzerland. Schweiz Arch Tierheilkde 141 361-366

HYDE, SR, BENIRSCHKE, K 1997: Gestational psittacosis: Case report and literature review. Modern Pathology 10: $602-607$

JONES, GE, LOW, JC, MACHELL, J, ARMSTRONG, K 1997: Comparison of five tests for the detection of antibodies against chlamydial (enzootic) abortion in ewes. Vet Rec 141: 164-168

KALTENBOECK, B, HEARD,D, DEGRAVES, FJ, SCHMEER, N 1997: Use of synthetic antigens improves detection by enzyme-linked immunosorbent assay of antibodies against abortigenic Chlamydia psittaci in ruminants. J Clin Microbiol 35: 2293-2298

KENNEDY, HE, MCCULlOUGH, SJ, GRAHAM, D, CASSIDY, J, MALONE, FE, ELLIS, WA 2001: Detection of chlamydial antibody by fetal serology- an aid to the diagnosis of ovine abortion. J Vet Diagn Invest 13: $30-35$

LONGBOTTOM, D, PSARROU, E, LIVINSTONE, M, VRETOU, E 2001: Diagnosis of ovine abortion using an indirect ELISA (rOMP91B iELISA) based on a recombinant protein fragment of the polymorphic outer membrane protein POMP91B of Chlamydophila abortus. FEMS-Microbiol Letters 195: 157-161

Manual of Standards for Diagnostic Tests and Vaccine 2000: Office International des Epizooties, pp. 515-521

MARTIN, SW, MEEK, AH, WILLEBERG, P 1988: Veterinary Epidemiology - Principles and Methods, Iowa State University Press, pp. 73-76

PAPP, JR, SHEWEN, PE 1996: Pregnancy failure following vaginal infection of sheep with Chlamydia psittaci prior to breeding. Infection and Immunity 64: 1116-1125

POSPÍŠIL, L, VĚŽNÍK, Z, HIRT, M, ŠVECOVÁ, D, DIBLÍKOVÁ, I, PEJČOCH M 1996: Demonstration of Chlamydia sp. in Intestines and Lungs of Pigeons and Human Corpses. Epidemiol Mikrobiol Imunol 45: $123-126$

SALTI-MONTESANTO, V, TSOLI, E, PAPAVASSILIOU, P, PSARROU, E, MARKEY, BK, JONES, GE, VRETOU, E 1997: Diagnosis of ovine enzootic abortion, using a competitive ELISA based on monoclonal antibodies against variable segments 1 and 2 of the major outer membrane protein of Chlamydia psittaci serotype 1. Amer J Vet Res 58: 228-235

TRÁVNIČEK, M, KOVÁČOVÁ, D, ZUBRICKY,P, ČISLÁKOVÁ, L 2001: Serosurvey of sheep and goats to Chlamydia psittaci in Slovakia during the years 1996-2000. Vet Med - Czech, 46: 281-285

VĚŽNíK, Z, POSPÍŚIL, L 1997: Chlamydial Infections (in Czech), Ed. DVPZ Brno, Czech Republic, 163 p 